\title{
ANALISIS JANUARY EFFECT PADA SAHAM ASTRA INTERNASIONAL (ASII) DI BURSA EFEK INDONESIA PADA PERIODE 2005 - 2015
}

\author{
Andreas Kiky \\ Universitas Multimedia Nusantara \\ Andreas.kiky@umn.ac.id
}

\begin{abstract}
In Stock Market our goal is pursue optimum wealth by appreciation of our Stocks. Stock price fluctuate over time as nobody can predict. In this research our aim is to observe the market anomaly that might be happened as the investor behave. We will examine January Effect as Keim observe in 1986 in Indonesia Stock Exchange. Also we can also examine Efficient Market Hypothesis as the result from anomaly and abnormal return that founded in this research. If we can find the market anomaly perhaps we can map the market seasonal trend as the past data recorded. If this anomaly exists we could suggest investor to invest their money as the anomaly data shown. Then investor could gain optimum wealth base on this information.

Purpose of this paper is to examine market anomaly and does it exist in Indonesia market? Our main objective is to predict the market movement base on seasonal or anomaly pattern that has been found in previous research. We use CAPM to measure Expected Return of Asset and we use ASII stock price to measure the return of the stock. Our finding is far from our expectation. We expect to find January Effect here but unfortunately we found another anomaly that happen in May and October. Our research suggest that we should cautious for this investor behavior because they seem react as the new information or news appear
\end{abstract}

\section{Keywords: Abnormal Return, January-Effect, Market Anomaly, CAPM, Efficient Market Hypothesis}

\section{Pendahuluan}

Dalam ilmu investasi, tujuan utama dalam kegiatan tersebut adalah tambahan kekayaan ataupun tambahan kesejahteraan. Akan tetapi menjadi sebuah tantangan untuk berinvestasi di pasar modal karena pergerakan harga saham yang terlalu fluktuatif dan tidak dapat diprediksi. Kajian fundamental untuk melihat fundamental sebuah perusahaan biasanya menjadi sebuah acuan penting dalam pemilihan pertama sebuah saham atau pembentukan portofolio. Jones (2005) menunjukan return yang diperoleh dari investasi pada sebuah saham terdiri atas 2 komponen utama yakni capital gain dan dividend. Sebuah perusahaan yang baik secara fundamental seharusnya memiliki nilai yang terus naik di masa yang akan datang. Namun pada kenyataannya tidak demikian. Ditemukan beberapa fenomena di mana perusahaan yang memiliki nilai fundamental yang baik tidak selalu menunjukan pertumbuhan harga saham yang tinggi. Ross (2014) menunjukan dalam penilaian laporan keuangan penting sekali melihat 5 aspek seperti likuiditas jangka pendek, likuiditas jangka panjang, aset manajemen, profitabilitas perusahaan dan nilai pasar. Seharusnya perusahaan yang 
menunjukan indikator baik dari laporan keuangan tersebut memiliki harga yang tinggi. Fenomena seperti ini telah lama ingin diteliti oleh peneliti ilmu keuangan atau lebih khususnya peneliti pasar modal. Kajian mengenai anomaly tersebut sudah diteliti sejak lama. Banz (1981) menemukan size-effect yang mengacu pada temuan bahwa perusahaan dengan kapitalisasi kecil mampu menghasilkan return yang lebih tinggi dibandingkan perusahaan dengan kapitalisasi besar. Keim (1986) lebih lanjut menemukan January-effect yang menyatakan bahwa abnormal return yang terjadi pada bulan Januari relative lebih tinggi dibandingkan 11 bulan yang lain. Anomali pasar seperti ini menjadi sebuah topik yang hingga saat ini belum ditemukan jawaban pastinya.

Tindakan investor atau para pemegang saham terkadang lebih cenderung ke arah tidak rasional dan menjadi sulit untuk diprediksi. Kajian penelitian ini bertujuan untuk membuka gerbang penelitian lebih lanjut ke arah ilmu psikologi pasar modal. Atau lebih dikenal dengan behavioral finance. Anomali dan abnormal return yang masih sering terjadi menjadi sangat sulit untuk pembuktian secara empiris pada setiap model yang diajarkan pada ilmu investasi. Tujuan dari penelitian ini adalah menjawab apakah terjadi January Effect pada saham Astra Internasional (ASII) dengan menggunakan Indeks Harga Saham Gabungan (IHSG) sebagai indikator pasar di Bursa Efek Indonesia. ASII dipilih menjadi sampel penelitian dengan alasan likuiditas perusahaan yang tinggi di Bursa Efek Indonesia. Saham yang memiliki likuiditas tinggi memiliki kecenderungan yang tinggi untuk terjadi anomaly karena banyaknya transaksi oleh investor memungkinkan harga bergerak dengan sangat fluktuatif. Diharapkan dengan menjawab fenomena ini maka penelitian ini dapat berkontribusi pada pemetaan tipe investor di Indonesia. Hasil dari penelitian ini diharapkan berbeda dengan penelitian sebelumnya dan dapat memberikan informasi khusus dan unik sesuai dengan karakteristik suatu perusahaan. Umumnya anomaly pasar juga terkait dengan sebuah event seperti pembagian dividen dan beberapa kebijakan perusahaan yang dapat berakibat pada reaksi investor. Sedangkan pada penelitian ini peneliti berfokus pada fenomana naiknya harga saham hanya pada bulan tertentu saja.

\section{Tinjauan Literatur dan Hipotesis}

Studi mengenai behavioral finance telah lama dimulai. Studi ini mengkaji perilaku irrational dari investor terkait dengan pengambilan keputusan investasi. Dalam ilmu keuangan dan investasi, umumnya dalam menelaah perilaku investor asumsi dasar yang digunakan adalah investor adalah orang yang rasional. Yang dimaksud dengan rasional ini adalah investor cenderung menghindari risiko dan mengambil keputusan berdasarkan risiko dari suatu investasi. Akan tetapi dalam praktiknya masih banyak faktor berita atau issue yang menjadi pemicu pengambilan keputusan seorang investor dan akibatnya investor cenderung tidak rasional. Dalam ilmu keuangan dan penilaian asset tentunya asumsi dasar tersebut diperlukan untuk membentuk sebuah model penilaian asset. Umumnya untuk menilai return yang diharapkan para praktisi keuangan umumnya menggunakan CAPM atau yang disebut juga Capital Asset Pricing Model. Model CAPM sendiri diperkenalkan oleh Sharpe dan Lintner (1964). Model ini menjelaskan hubungan antara risiko dan return dari suatu aset. CAPM sendiri membagi risiko menjadi dua kategori risiko yakni risiko sistematis dan non-sistematis. Untuk risiko sistematis diukur berdasarkan risiko-bebas (risk free) yang merupakan tingkat pengembalian bebas risiko atau di Indonesia adalah nilai dari SBI. SBI mengakomodir risiko makro ekonomi secara menyeluruh. Sedangkan untuk risiko non-sistematis terdapat pada Beta dari masing-masing karakteristik suatu sekuritas ataupun industry tersebut. Total risiko dari suatu aset adalah penjumlahan dari risiko sistematis dan risiko non-sistematis. Oleh karena itu CAPM akan menjadi dasar pada penelitian untuk menghitung expected return sesuai dengan kajian teoritis tersebut.

Adapun model CAPM dapat terangkum dalam rumus berikut ini: 


\section{Persamaan 2.1. Rumus CAPM}

$$
R i=R f+\beta(R m-R i)+\varepsilon
$$

Keterangan:

$$
\begin{array}{ll}
\mathrm{R}_{\mathrm{i}} & =\text { Return Asset } \\
\mathrm{R}_{\mathrm{f}} & =\text { Risk Free Return } \\
\beta & =\text { Beta / Slope Koefisien } \\
\mathrm{R}_{\mathrm{m}}-\mathrm{R}_{\mathrm{f}} & =\text { Market Premium } \\
\varepsilon_{\mathrm{i}} & =\text { Error }
\end{array}
$$

Untuk menghitung Actual Return maka peneliti akan menggunakan pendekatan Jones (2005). Jones (2005) menyatakan return merupakan jumlah dari capital gain dan juga dividend yang dibagikan oleh suatu sekuritas. Dengan kata lain maka rumus actual return dapat ditulis juga sebagai berikut:

\section{Persamaan 2.2. Rumus Perhitungan Actual Return}

Keterangan:

$\begin{array}{ll}\mathrm{R}_{\text {actual }} & =\text { Actual Return } \\ \mathrm{P}_{\mathrm{t}} & =\text { Price at time }{ }_{t} \\ \mathrm{P}_{\mathrm{t}-1} & =\text { Price at time }{ }_{t-1} \\ \mathrm{D}_{\mathrm{t}} & =\text { Dividend at time }{ }_{t}\end{array}$

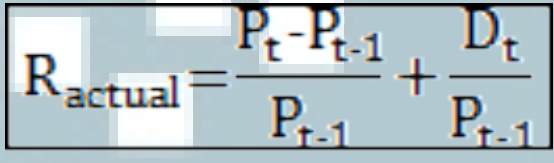

Malkiel dan Fama (1970) menemukan bahwa pasar terbagi atas tiga kategori bentuk. Ketiga bentuk pasar ini mencoba untuk menghubungkan keterbukaan informasi dan reaksi dari pasar. Secara umum berdasarkan riset Fama tersebut pasar terbagi atas 3 bentuk, yakni weak form, semi-strong form dan strong form. Jika pasar masuk dalam bentuk weak form maka dapat dikatakan harga saham yang terbentuk hanya mencerminkan informasi masa lalu dari performa perusahaan. Jika pasar masuk dalam bentu semi-strong form maka harga pasar yang terbentuk merupakan refleksi dari informasi performa perusahaan saat ini. Dan jika perusahaan masuk dalam strong form maka harga pasar telah mencerminkan informasi publik dan privat. Akibatnya pada kondisi strong form market maka tidak dapat terjadi abnormal return yang timbul sebagai akibat dari informasi privat. Kajian ini dikenal dengan teori pasar effisien atau efficent market hypothesis. Umumnya teori ini yang digunakan sebagai building block untuk mengkaji peristiwa anomali pasar dalam ilmu investasi dan pasar modal. Kajian CAPM juga menuai banyak kritik. Bahkan Corrado (2009) menyatakan secara empiris anomali pasar terbentuk akibat market inefficientcy. Roll (1988) memberikan kritik dan secara empiris nilai $\mathrm{R}^{2}$ dari model CAPM hanya sebesar 0.35 dengan penggunaan data bulanan. Sedangkan nilai itu turun menjadi lebih kecil lagi dan menjadi sebesar 0.2 dengan 
penggunaan data harian. Oleh karena itu penelitian ini dirasa menarik untuk mengkaji fenomena reaksi pasar dan juga anomaly pasar yang umumnya terjadi dalam dunia investasi.

Untuk berbicara mengenai fenomena anomaly ini maka penting sekali bagi kita untuk mengerti market bubble dan crush. Stiglitz (1990) mendefinisikan buble dan alasan terjadinya karena para investor percaya bahwa harga di hari esok akan jauh lebih tinggi dibandingkan faktor fundamental dari aset tersebut. Oleh karena itu, ini akan membawa kepada kepercayaan diri yang berlebihan dan akibatnya menjadi sebuah justifikasi dalam pembelian suatu aset. Warneryd (2001) lebih jauh menjelaskan teori pasar efisien berusaha untuk menjelaskan fenomena anomaly pasar berdasarkan ketersediaan informasi yang ada. Selain itu EMH juga merupakan sebuah komplemen dari model CAPM yang tidak dapat menjelaskan anomaly yang terjadi. Selain itu dari sudut pandang psikologi, pada umumnya sistem berpikir manusia terbagi atas 2 sistem yakni sistem yang berpikir secara cepat dan sistem yang menuntut kita untuk berpikir dan menalar terlebih dahulu. Kahneman (2013) menyatakan salah satu sistem atau yang disebut dengan sistem 1 yang memiliki waktu respon pendek dan cepat cenderung membawa kita pada kesalahan penilaian apalagi jika kita memiliki tingkat kepercayaan diri yang berlebihan.

Selanjutnya jika memang terjadi inefficiency di pasar maka yang mungkin akan terjadi adalah abnormal return. Untuk menghitung abnormal return ini maka peneliti menggunakan pendekatan Jones (2005) yakni:

Keterangan:

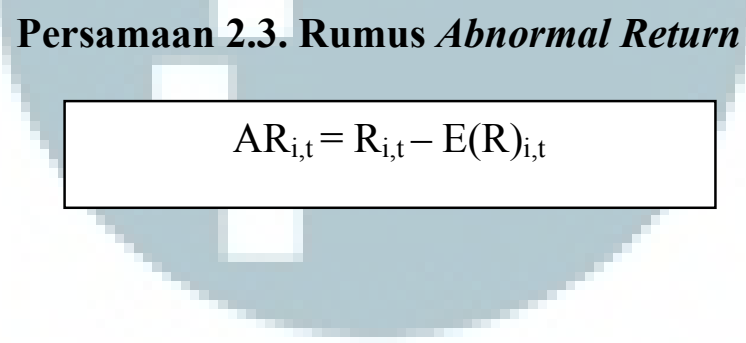

$\mathrm{AR}_{\mathrm{i}, \mathrm{t}}=$ Abnormal Return untuk aset $\mathrm{i}$, pada periode $\mathrm{t}$.

$\mathrm{R}_{\mathrm{i}, \mathrm{t}} \quad=$ Actual Return untuk aset $\mathrm{i}$, pada periode $\mathrm{t}$.

$\mathrm{E}(\mathrm{R})_{\mathrm{i}, \mathrm{t}}=$ Expected Return untuk aset $\mathrm{i}$, pada periode $\mathrm{t}$

Selain itu kita juga dapat menghitung Cumulative Abnormal Return berdasarkan formula di bawah ini:

\section{Persamaan 2.4. Rumus Cummulative Abnormal Return}

$$
\mathrm{CAR}_{\mathrm{i}, \mathrm{t}}=\sum_{\mathrm{t}=1}^{\mathrm{n}} \mathrm{AR}_{\mathrm{i}, \mathrm{t}}
$$

Keterangan:

$\mathrm{CAR}_{\mathrm{i}, \mathrm{t}}=$ Cumulative Abnormal Return untuk aset i pada periode $\mathrm{t}$.

ARi,t $=$ Abnormal Return untuk aset i pada periode $\mathrm{t}$. 
Penelitian ini tertarik dengan fenomena January Effect. Fenomena ini ditemukan pertama kali oleh Keim (1986) yang mana menemukan ternyata harga saham cenderung menjadi tinggi pada bulan Januari, sedangkan pada bulan Desember sebelumnya cenderung rendah sebagai akibat aksi jual oleh investor. Efek seasonal ini terjadi pada bursa Amerika Serikat. Oleh karena itu penelitian ini tertarik untuk mengkaji efek seasonal ini pada bursa efek Indonesia. Hanya saja karena keterbatasan waktu yang peneliti kaji dalam penelitian ini hanya saham ASII dan IHSG selama periode penelitian yakni dari tahun 2005 - 2014. Expected Return yang peneliti gunakan sesuai dengan model CAPM dan akan dihitung tiap bulannya. Selanjutnya peneliti akan menghitung abnormal return yang terjadi dan juga cumulative abnormal return yang terjadi.

\section{Metode Penelitian}

Objek penelitian ini adalah Indeks Harga Saham Gabungan (IHSG) dari tahun 2005 hingga tahun 2014. Selanjutnya penelitian ini akan melewati tahap-tahap berikut ini.

1. Data IHSG akan dikumpulkan secara harian dari tahun 2005 hingga tahun 2015.

2. Data harga saham ASII akan dikumpulkan secara harian dari tahun 2005 hingga tahun 2015. Saham ASII dipilih dengan alasan likuiditas transaksi harian saham tersebut.

3. Data IHSG dan harga saham akan dihitung return saham sesuai dengan rumus untuk menghitung actual return setiap harinya sehingga akan terdapat data return harian.

4. Untuk menghitung risk free maka digunakan data SBI sesuai dengan data dari Bank Indonesia.

5. Data return yang telah dikumpulkan akan dikelompokan sesuai dengan bulan transaksi sehingga akan terbentuk kumpulan return per bulan untuk mengestimasi expected return dengan menggunakan model CAPM.

6. Dengan menggunakan model CAPM maka kita dapat menghitung intercept dan juga slope setiap bulan dari sampel. Intercept dan slope ini akan digunakan untuk menghitung expected return setiap bulannya.

7. Peneliti juga menghitung actual return setiap bulannya sehingga akan dibandingkan antara actual return dan expected return yang nantinya akan menghasilkan abnormal return.

8. Setelah mendapatkan nilai abnormal return maka kita dapat mengkaji nilai abnormal return yang terjadi untuk menalaah anomali yang terjadi.

Variabel penelitian ini adalah abnormal return. Nilai dari abnormal return akan dibandingkan secara berkala dengan realized return dari tahun 2005 hingga tahun 2015. Realized return akan dihitung setiap bulannya sesuai dengan performa harian dari saham ASII. Peneliti menggunakan uji t untuk menguji tingkat signifikasi dari abnormal return tersebut. 


\section{Hasil dan Pembahasan}

Berikut merupakan hasil ringkasan rata-rata actual return dan return market:

Tabel 4.1. Ringkasan Hasil Rata-Rata Actual Return dan Return Market

\begin{tabular}{lrrrrrrrrrrr}
\hline Indicator & 2005 & 2006 & 2007 & 2008 & 2009 & 2010 & 2011 & 2012 & 2013 & 2014 & 2015 \\
\hline Return (Ri) & $0.83 \%$ & $0.54 \%$ & $1.14 \%$ & $0.27 \%$ & $2.29 \%$ & $1.10 \%$ & $0.18 \%$ & $0.01 \%$ & $0.07 \%$ & $0.82 \%$ & $0.73 \%$ \\
$\begin{array}{l}\text { Return Market } \\
(\mathrm{Rm})\end{array}$ & $0.90 \%$ & $4.04 \%$ & $3.94 \%$ & $6.13 \%$ & $6.37 \%$ & $3.44 \%$ & $0.59 \%$ & $1.15 \%$ & $0.16 \%$ & $1.52 \%$ & $-0.95 \%$ \\
\hline
\end{tabular}

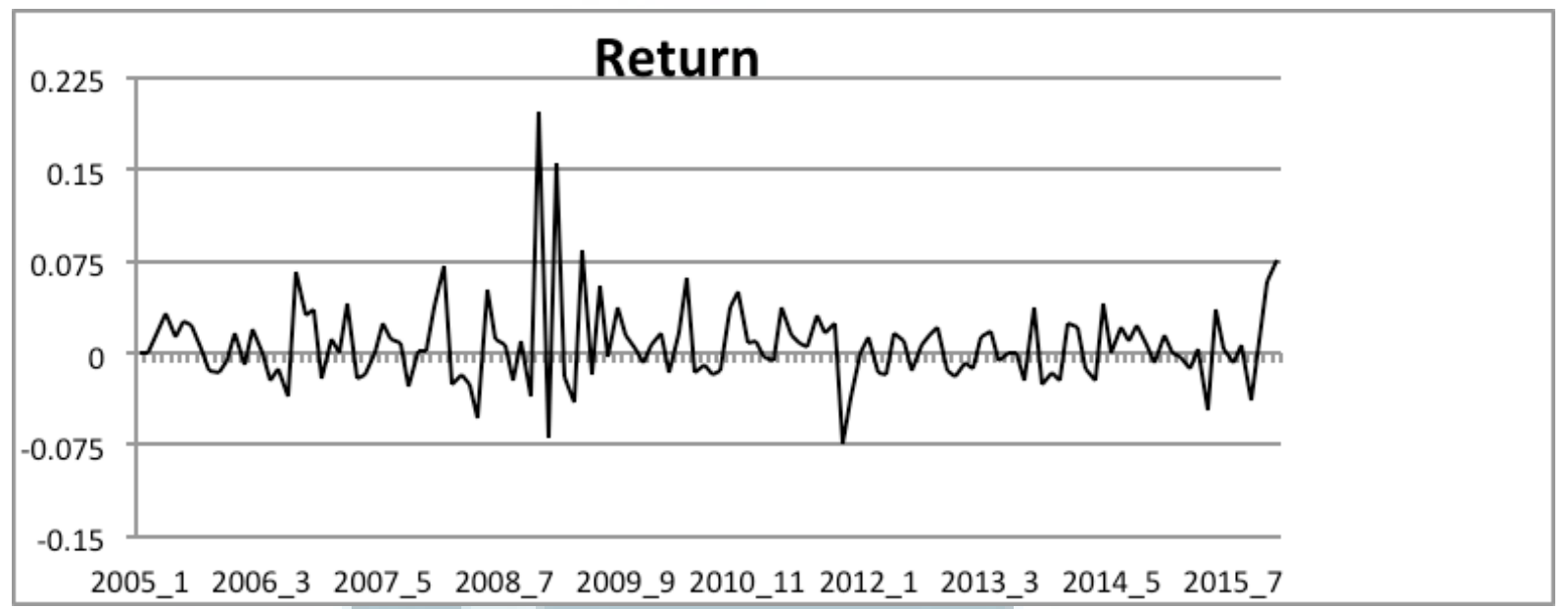

Grafik 4.1. Nilai Actual Return dari Saham ASII

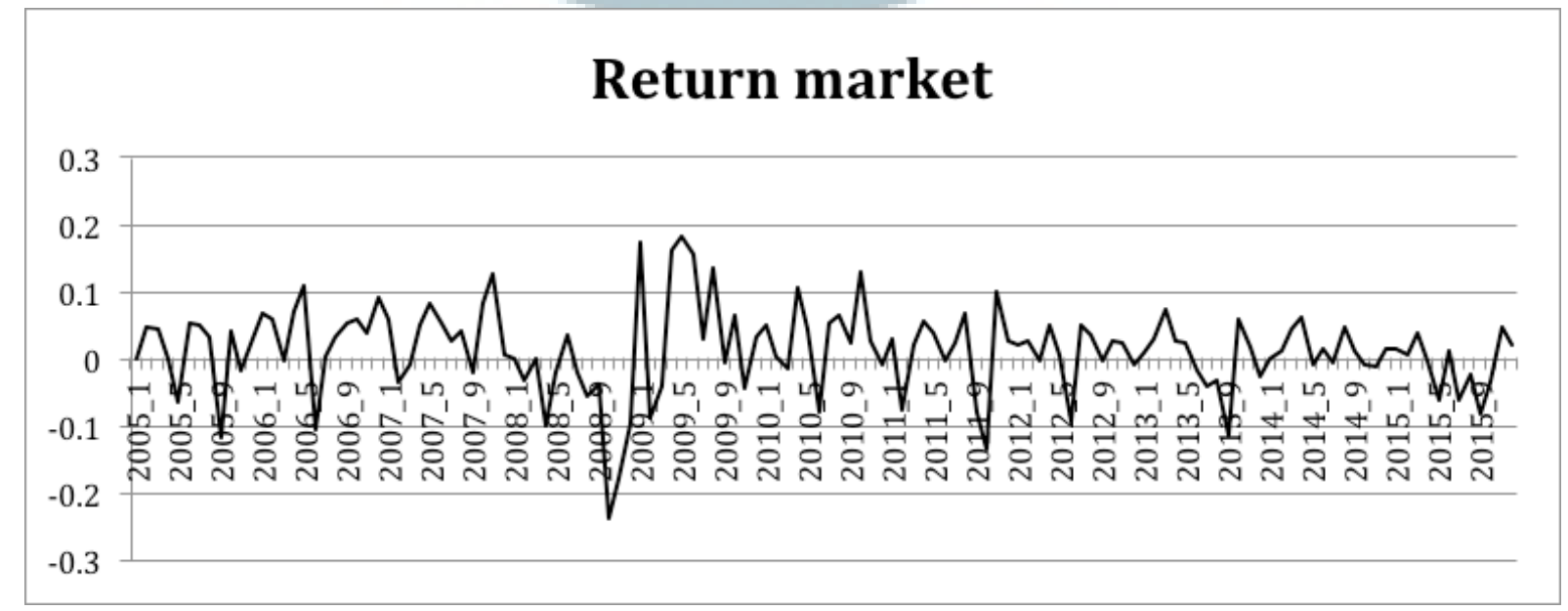

Grafik 4.2. Nilai Return Market

Berdasarkan hasil deskriptif dapat terlihat actual return dari saham ASII kurang lebih memiliki pergerakan yang mirip dengan return market. Akan tetapi pada tahun 2009 pasar mengalami penurunan yang tajam yakni sekitar $-0.2 \%$ pada kuarter ke-3 2009. Hanya saja ternyata performa saham ASII jauh lebih baik dari pasar. Sesuai dengan persamaan CAPM 
maka ada kemungkinan terjadi abnormal return untuk situasi tersebut. Akan tetapi jika diperhatikan pada setiap bulan January, actual return yang terjadi relatif mirip dengan performa pasar. Tentunya yang menjadi fokus pada penelitian ini adalah abnormal return yang mungkin terjadi pada bulan Januari. Selanjutnya pada tabel dibawah ini peneliti paparkan nilai intercept dan slope yang berhasil peneliti peroleh dengan menggunakan model CAPM. Untuk memperoleh nilai intercept dan slope ini peneliti menggunakan data bulanan dari return saham dan juga return market.

\section{Tabel 4.2. Hasil Actual Return, Expected Return dan Abnormal Return setiap bulan Januari}

\begin{tabular}{rrrr}
\hline Tahun & Actual Ri & Exp Ri & $\begin{array}{r}\text { Abnormal } \\
\mathrm{r}\end{array}$ \\
\hline 2005 & 0 & $-0.01 \%$ & $0.01 \%$ \\
2006 & $-0.98 \%$ & $10.03 \%$ & $-11.01 \%$ \\
2007 & $4.14 \%$ & $6.13 \%$ & $-1.99 \%$ \\
2008 & $-2.56 \%$ & $0.54 \%$ & $-3.11 \%$ \\
2009 & $15.64 \%$ & $30.69 \%$ & $-15.05 \%$ \\
2010 & $1.73 \%$ & $7.55 \%$ & $-5.82 \%$ \\
2011 & $-0.27 \%$ & $2.72 \%$ & $-2.99 \%$ \\
2012 & $1.35 \%$ & $2.63 \%$ & $-1.28 \%$ \\
2013 & $-1.32 \%$ & $1.67 \%$ & $-2.98 \%$ \\
2014 & $2.21 \%$ & $-0.31 \%$ & $2.52 \%$ \\
2015 & $-0.34 \%$ & $3.18 \%$ & $-3.52 \%$ \\
\hline
\end{tabular}

Berdasarkan hasil tersebut dapat kita lihat abnormal return yang terjadi relatif kecil, hanya pada tahun 2006 dan 2009 saja yang menunjukan hasil yang cukup tinggi. Akan tetapi hasil abnormal return yang terjadi pada tahun 2006 dan 2009 menunjukan hasil yang negatif. Hal ini bertentangan dengan hipotesis penelitian yang menduga bahwa seharusnya terjadi abnormal return yang positif pada bulan Januari. Selanjutnya peneliti menggunakan regresi untuk data bulanan tersebut untuk mengukur signifikansi dari nilai abnormal return yang terjadi. Hipotesis penelitian ini adalah:

$\mathrm{H}_{0} \quad$ : Tidak terjadi abnormal return selama periode $\mathrm{t}$

$\mathrm{H}_{\mathrm{a}} \quad$ : Terjadi abnormal return selama periode $\mathrm{t}$

Tabel 4.3. Hasil Regresi Data Bulanan tahun 2005 hingga tahun 2014

\begin{tabular}{rr}
\hline Indikator & Value \\
\hline Intercept & 0.014384559 \\
Beta & 0.118510077 \\
Standard & 0.033547751 \\
Error & \\
R2 & 0.056306409 \\
\hline
\end{tabular}


Selanjutnya berdasarkan regresi tersebut maka peneliti mengkaji nilai signifikansi abnormal return dengan menggunakan uji t. Hasil yang peneliti peroleh adalah sebagai berikut:

Tabel 4.5. Hasil Uji t Abnormal Return

\begin{tabular}{lllllllllllllll}
\hline Thn/bln & & 1 & 2 & & 3 & 4 & 5 & 6 & 7 & 8 & 9 & 10 & 11 & 12 \\
\hline 2005 & no & yes* & no & no & yes* & no & no & no & yes* & yes* & no & no \\
2006 & yes* & yes* & no & yes* & yes* & no & no & no & no & yes* & no & yes* \\
2007 & no & no & no & no & yes* & no & no & no & no & yes* & yes* & no \\
2008 & no & no & no & yes* & yes* & no & no & no & no & yes* & yes* & yes* \\
2009 & yes* & no & no & yes* & yes* & yes* & no & no & no & yes* & no & no \\
2010 & no & no & no & yes* & yes* & no & yes* & yes* & no & yes* & no & no \\
2011 & no & yes* & no & yes* & no & no & no & yes* & yes* & no & yes* & no \\
2012 & no & no & no & no & no & yes* & yes* & no & no & yes* & no & no \\
2013 & no & no & no & no & no & no & no & yes* & yes* & yes* & no & no \\
2014 & no & no & yes* & yes* & no & no & no & no & no & no & no & no \\
2015 & no & no & no & no & yes* & no & yes* & no & yes* & yes* & no & no \\
\hline
\end{tabular}

* menunjukan bahwa hasil uji t signifikan

Berdasarkan hasil uji statistik ditemukan bahwa yang menjadi sasaran penelitian ini, January Effect hanya ditemukan 2x signifikan, yakni pada tahun 2006 dan tahun 2009. Pengujian ini tidak menggunakan uji normalitas karena berfokus pada tujuan penelitian menemukan anomaly dalam periode tertentu. Sebaran titik data juga sudah melebihi dari 50 titik data yang jika mengacu kepada central limit theorem maka sudah cukup untuk membentuk bell-shape pola distribusi normal. Selebihnya peneliti menemukan bahwa anomaly dan abnormal return terjadi cukup banyak di pertengahan tahun yakni pada bulan Mei dan juga bulan Oktober. Tentu saja kajian ini masih jauh dari sempurna dan juga dikarenakan keterbatasan sampel maka tentunya hasil ini masih harus dikritisi lebih lanjut. Tentunya dalam penelitian ini menurut peneliti pemicu yang bisa menjadi alasan terjadinya abnormal return pada kuarter keempat setiap tahunnya adalah aksi beli oleh investor. Memasuki akhir tahun maka tentunya perusahaan mempersiapkan laporan akhir tahun yang menjadi indikator kemajuan suatu perusahaan. Seiring dengan diterbitkannya laporan ini bisa jadi investor mulai melakukan aksi beli untuk dan termotivasi untuk melakukan pembelian. Hal ini tentunya didukung dengan bonus ataupun THR yang bisa jadi merupakan sumber dana bagi investor dalam melakukan pembelian. Implikasi dari penelitian ini adalah mengkonfirmasi bahwa benar adanya terjadi anomaly di pasar Indonesia. Akan tetapi ternyata penelitian ini menemukan anomaly yang berbeda dengan penelitian terdahulu. Peneliti berargumen bahwa anomaly ini dapat terjadi sebagai akibat dari perilaku investor yang tidak dapat diprediksi dengan sangat akurat. Aksi jual dan beli serta reaksi investor sangat rentan dengan berita dan juga ketersediaan dana. Menurut peneliti, saat bulan Oktober kemungkinan besar yang menjadi pemicu aksi beli yang tinggi ini diakibatkan ketersediaan uang dari investor. Hal ini terkait dengan adanya THR untuk Idul Fitri sehingga memungkinan investor berinvestasi lebih banyak. Terkait untuk bulan Mei, peneliti sendiri masih belum bisa menjawab fenomena tersebut. Dan jika hal ini terkait dengan ketersediaan uang untuk melakukan aksi beli, maka 
hal ini juga mengkonfirmasi pada bulan January yang tidak terjadi anomaly diakibatkan belanja akhir tahun ataupun meningkatnya konsumsi rumah tangga pada akhir dan awal tahun. Dengan kata lain investor tidak lagi melakukan aksi beli melainkan kemungkinan besar melakukan aksi jual terkait dengan kebutuhan konsumsi tersebut.

Sekali lagi hasil ini masih jauh dari sempurna, ada baiknya hasil ini juga mulai dibandingkan dengan berbagai sampel berbeda tidak hanya melibatkan satu perusahaan saja sebagai sampel. Jika memungkinkan pengembangan penelitian mencakup sampel dari 9 kategori sektor industry dari Bursa Efek Indonesia.

\section{Simpulan, Keterbatasan, dan Saran}

\section{Simpulan}

Hasil penelitian ini masih cukup berbeda dari tujuan utama penelitian. Hanya saja masih sejalan dengan topik anomaly pasar, peneliti menemukan terjadi anomaly. Akan tetapi yang berbeda dari hasil yang peneliti harapkan adalah ternyata anomaly yang terjadi bukan terjadi pada bulan Januari akan tetapi terjadi pada bulan yang lain. January Effect tidak terbukti konsisten selama tahun penelitian. Akan tetapi peneliti menemukan October Effect pada penelitian ini. Tentunya perilaku investor, aksi jual dan beli menjadi faktor penentu utama terjadi hal ini. Peneliti sendiri menyadari hasil penelitian ini masih jauh dari sempurna dan masih harus diberikan tambahan dan kritik. Dari sisi sampel penelitian, penelitian ini hanya terbatas pada penggunaan sampel 1 perusahaan saja. Peneliti berpikir akan lebih baik jika pada akhirnya penelitian serupa dapat menambahkan sampel yang mencerminkan karakteristik setiap sektor industry di Bursa Efek Indonesia.

Hasil dari penelitian ini juga memberikan saran, bagi para praktisi keuangan dan investasi untuk tetap berhati-hati dengan anomaly pasar. Jika memang pada akhirnya pasar efisien dan harga pasar telah mencerminkan semua informasi ternyata temuan penelitian ini membantah hal tersebut. Masih terdapat beberapa abnormal return yang merupakan produk dari asymmetry information yang terjadi di pasar. Penting sekali bagi para investor untuk tetap memperhatikan momentum dan arus pasar sebelum mengambil keputusan untuk trading. Selain itu hasil dari model CAPM ternyata cukup kecil berdasarkan hasil dari nilai $\mathrm{R}^{2}$. Sekalipun demikian tidak ada model yang cukup teoritis untuk memberikan hubungan antara risk dan return dari suatu aset. Peneliti tetap berpegang pada landasan teoritis yang mendasari CAPM. Diharapkan hasil penelitian ini membuka gerbang penelitian bagi topic asymmetry information, market inefficiency dan juga anomaly pasar yang lain.

\section{Referensi}

Banz, Rolf W. (1981). "The Relationship Between Return and market Value of Common Stocks". Journal of Financial Economics, 9: 3 - 18.

Corrado, Charles J. (2009). Fundamental of Investment Valuation and Management. America: McGraw Hill Irwin.

Jones, Charles P. (2005). Investment Principles and Concept. North Carolina State: John Wiley.

Kahneman, Daniel . (2011). Thinking Fast and Slow. New York: Farrar, Straus and Giroux Publishing.

Keim, D. B. (1983). Size-related anomalies and stock return seasonality: Further empirical evidence. Journal of Financial Economics, 12: 13 - 32. 
Malkiel, B. G. \& Fama, E. F. (1970). "Efficient Capital Markets: A Review Of Theory And Empirical Work". The Journal of Finance, 25: 383-417.

Roll, R. (1988). $\mathrm{R}^{2}$. The Journal of Finance, 43: 541-566.

Sharpe, William F. (1964). "Capital Asset Prices: A Theory of Market Equilibrium under Condition of Risk". Journal of Finance, 19: 425 - 442.

Staglitz, J.E. (1990). "Symposium on Buble". Journal of Economic Perspective, 4 (3): 13-18.

Warneryd, Karl-Erik. (2001). Stock-Market Psychology. Cheltenham, UK: Edward Elgar Publishing.
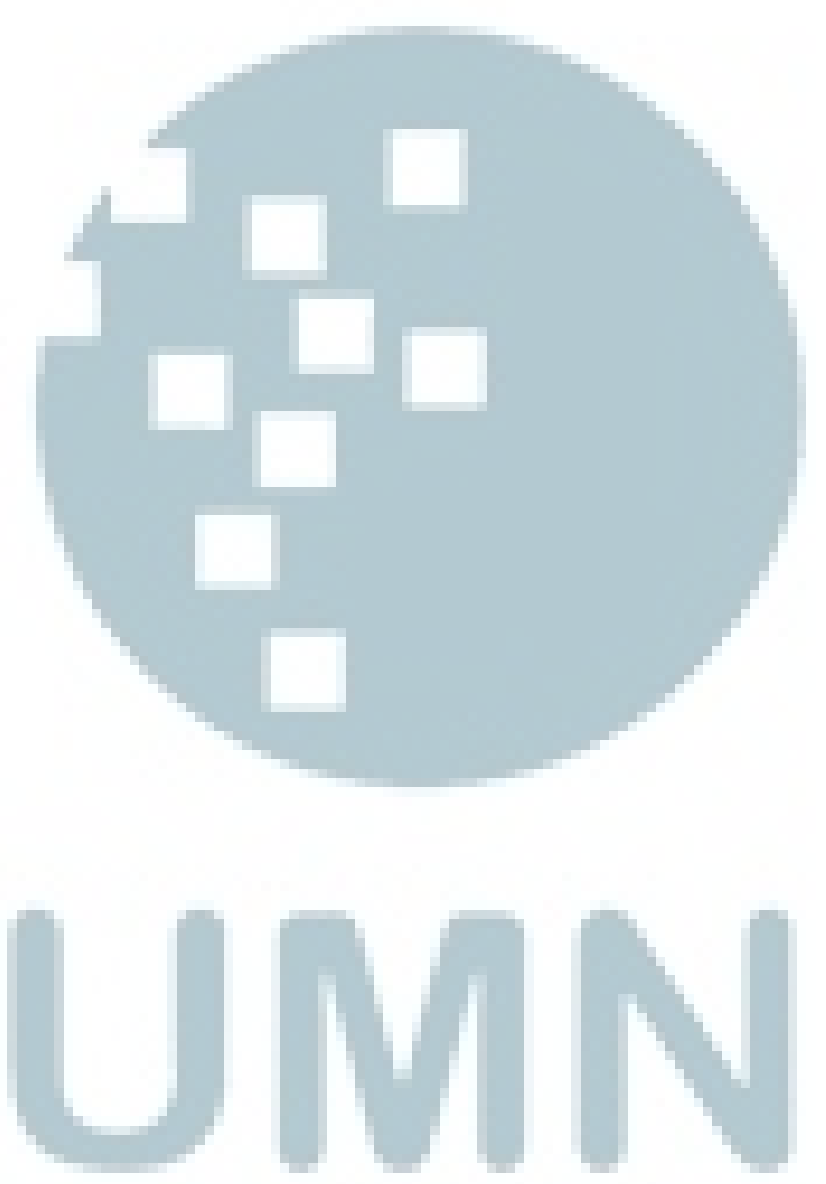